\title{
A novel and efficient fungal delignification strategy based on versatile peroxidase for lignocellulose bioconversion
}

\author{
Wen Kong ${ }^{1 \dagger}$, Xiao Fu $^{1 \dagger}$, Lei Wang ${ }^{1 \dagger}$, Ahmad Alhujaily ${ }^{1}$, Jingli Zhang ${ }^{2}$, Fuying Ma' ${ }^{1}$, Xiaoyu Zhang ${ }^{1}$ \\ and Hongbo $\mathrm{Yu}^{1 *}$
}

\begin{abstract}
Background: The selective lignin-degrading white-rot fungi are regarded to be the best lignin degraders and have been widely used for reducing the saccharification recalcitrance of lignocellulose. However, the biological delignification and conversion of lignocellulose in biorefinery is still limited. It is necessary to develop novel and more efficient bio-delignification systems.

Results: Physisporinus vitreus relies on a new versatile peroxidase (VP)-based delignification strategy to remove enzymatic recalcitrance of corn stover efficiently, so that saccharification of corn stover was significantly enhanced to $349.1 \mathrm{mg} / \mathrm{g}$ biomass (yield of glucose) and $91.5 \%$ (hydrolysis yield of cellulose) at 28 days, as high as levels reached by thermochemical treatment. Analysis of the lignin structure using pyrolysis-gas chromatography-mass spectrometry (Py-GC/MS) showed that the total abundance of lignin-derived compounds decreased by $54.0 \%$ and revealed a notable demethylation during lignin degradation by P. vitreus. Monomeric and dimeric lignin model compounds were used to confirm the ligninolytic capabilities of extracellular ligninases secreted by $P$. vitreus. The laccase (Lac) from $P$. vitreus could not oxidize nonphenolic lignin compounds and polymerized $\beta-O-4$ and $5-5^{\prime}$ dimers to precipitate which had a negative effect on the enzymatic hydrolysis of corn stover in vitro. However, the VP from $P$. vitreus could oxidize both phenolic and nonphenolic lignin model compounds as well as break the $\beta-0-4$ and $5-5^{\prime}$ dimers into monomeric compounds, which were measured by high-performance liquid chromatography-electrospray ionization-mass spectrometry (LC-ESI-MS). Moreover, we showed that addition of purified VP in vitro improved the enzymatic hydrolysis of corn stover by $14.1 \%$.
\end{abstract}

Conclusions: From the highly efficient system of enzymatic recalcitrance removal by new white-rot fungus, we identified a new delignification strategy based on VP which could oxidize both phenolic and nonphenolic lignin units and break different linkages in lignin. In addition, this is the first evidence that VP could break 5-5' linkage efficiently in vitro. Moreover, VP improved the enzymatic hydrolysis of corn stover in vitro. The remarkable lignin-degradative potential makes VP attractive for biotechnological applications.

Keywords: Physisporinus vitreus, Enzymatic recalcitrance removal, Versatile peroxidase, Corn stover, Biofuel, Lignin, 5-5' linkage

\footnotetext{
*Correspondence: yuhongbo@hust.edu.cn

†Wen Kong, Xiao Fu and Lei Wang contributed equally to this work

${ }^{1}$ College of Life Science and Technology, Huazhong University of Science

and Technology, Wuhan 430074, People's Republic of China

Full list of author information is available at the end of the article
} 


\section{Background}

The so-called second-generation biofuel technology aims to utilize the nonfood-based lignocellulosic biomass from agricultural by-products, perennial crops, forest residues, and pulp industries to avoid the food vs. fuel controversy [1]. Agricultural by-products, such as corn stover, are attractive feedstocks for the production of second-generation bioethanol because of their high abundance [2]. However, the presence of lignin in these lignocellulosic materials impedes the enzymatic digestibility of cellulose [3]. Thus, the degradation of lignin by thermochemical reaction is critical to remove enzymatic recalcitrance of lignocellulose and enhance the hydrolysis of cellulose $[4,5]$, but it is very expensive and produces a series of toxic compounds, such as black liquor which are harmful for the environment or human health, and furfural and 5-hydroxymethylfurfural which inhibit the downstream enzymatic hydrolysis and fermentation [6]. Therefore, biological delignification has been considered as an advantageous alternative, because it is low-cost, environmental friendly, and does not produce inhibitors to fermentation [7]. There are varied patterns of biomass components degradation by fungi. These patterns included predominant polysaccharide degradation (brown-rot), simultaneous degradation of all biomass components (white-rot), and selective degradation of lignin with cellulose preservation (selective white-rot) $[8$, 9]. Selective white-rot fungal pretreatment can improve enzymatic saccharification by degrading lignin. However, most biological delignification processes have very low hydrolysis yields $[10,11]$; thus, novel and more efficient bio-delignification systems are necessary.

In nature, lignin degradation is a multi-enzymatic process involving an array of accessory enzymes (such as producing hydrogen peroxides) in addition to the four major lignilolytic enzymes. Different fungal species have been reported to exhibit different degradation capacities towards lignin, and their efficiency mainly depends on the ligninolytic enzymes produced by the white-rot fungi [12-14], mainly including laccase (Lac, EC 1.10.3.2), manganese peroxidase (MnP, EC 1.11.1.13), lignin peroxidase (LiP, EC1.11.1.14), and versatile peroxidase (VP, EC 1.11.1.16) [12]. The production and activity of these enzymes as well as their ability to degrade lignin vary significantly in different species of white-rot fungi. Differences in the catalytic properties of these enzymes strongly affect lignin degradation [14]. Lacs possess relatively low redox potentials $(0.48-0.78 \mathrm{~V})$ that restrict their action to the oxidation of the nonphenolic lignin components [15]. However, a typical lignin polymer is $10-15 \%$ phenolic in composition, rendering up to
$80-90 \%$ of the nonphenolic polymer unreactive to Lac [16]. Although Lac mediator systems have extended the substrate range of Lac to include the oxidation of nonphenolic lignin model compounds, some studies demonstrated that the presence of 1-hydroxybenzotriazole (HBT), a common mediator, strongly favors the oxidation reaction pathways over the coupling reactions that lead to polymerization of lignin [17, 18]. Additionally, Lac does not cleave condensed structures, such as the $5-5^{\prime}$ model dimer, even in the presence of mediators [19]. Peroxidases exhibit a high redox potential $(0.8-1.2 \mathrm{~V})$, which is required for lignin modification and degradation of lignocellulosic biomass [15]. LiPs are strong oxidants that interact directly with nonphenolic lignin structures to cleave them but they do so inefficiently and apparently cannot penetrate the small pores in sound lignocellulose. MnPs produce small diffusible strong oxidants that can penetrate the substrate but they cleave the principal structures of lignin with low yields [13]. VPs are structurally LiP-like hybrid MnPs with a high redox potential, which combine the catalytic properties of LiPs and MnPs [20-22]. Thus, VPs possess extraordinarily wide substrate specificity and can oxidize both low and high redox potential compounds [23, 24]. The unique properties of VPs strongly suggest that they contribute to ligninolysis; however, the role of VPs in fungal delignification has not been reported before and their relative importance remains unclear. So far, VPs have not been used successfully to delignify intact lignocellulose in vitro.

Physisporinus sp., a white-rot basidiomycete, degrades lignin selectively and has a noteworthy biotechnological potential [25]. The white-rot fungus Physisporinus vitreus is currently tested for several biotechnological applications such as biopulping of softwood, permeability improvement of refractory wood species, and biopretreatment [26]. Its efficiency in these processes has been mainly attributed to the release of a battery of ligninolytic enzymes. Screening of the enzymatic activity during wood degradation shows that $P$. vitreus secreted high amounts of laccase, while the peroxidases (Lip, MnP, and VP) were not detected [27].

This study is the first to report a novel and efficient delignification strategy for enzymatic recalcitrance removal of corn straw based on VP from selective lignin-degrading fungus $P$. vitreus. The effect of fungal delignification on enzymatic hydrolysis was evaluated. In addition, we further characterized lignin degradation by VP using different monomeric and dimeric lignin model compounds. Finally, we studied the enhancement of the enzymatic hydrolysis of corn stover by VP in vitro. 


\section{Results and discussion}

Enzymatic hydrolysis, component analysis, and enzyme production during pretreatment of corn stover with $P$. vitreus

As shown in Fig. 1a, corn stover without pretreatment were much more resistant to enzymatic hydrolysis and the yield of glucose only was $119.8 \mathrm{mg} / \mathrm{g}$ corn stover after 72-h hydrolysis. The conversion ratio of cellulose in raw corn stover was only $26.1 \%$. Higher glucose yields and cellulose conversion ratio were achieved when the corn stover pretreated with $P$. vitreus. There was a rapid increase in the glucose yield and cellulose conversion ratio with increasing pretreatment time before 28-day pretreatment. At the same time, it can be easily seen that the weight loss of corn stover increased with an increasing pretreatment time. Thus, the glucose yield and cellulose conversion ratio after enzymatic hydrolysis were used to evaluate the effect of pretreatment by taking the weight loss into consideration. The maximum glucose yield and cellulose conversion ratio reached up to $349.1 \mathrm{mg} / \mathrm{g}$ corn stover and $91.5 \%$ after 28 days of pretreatment, increasing by 2.9 and 3.5 times, respectively, compared with untreated corn stover. The conversion of cellulose to glucose was higher than the fungal pretreatments reported previously [28, 29], and similar to that of biomass pretreated with thermochemical processes $[5,6,30]$. The hydrolysis yields of various substrates by different fungal strains reported previously are usually ranging from 30 to $83 \%$ [29]. The hydrolysis yields of straw pretreated with thermochemical processes are usually about $80-100 \%$ [5]. Compared to thermochemical pretreatment, biological delignification has been considered as an advantageous alternative, because it is low-cost, environmental friendly, and
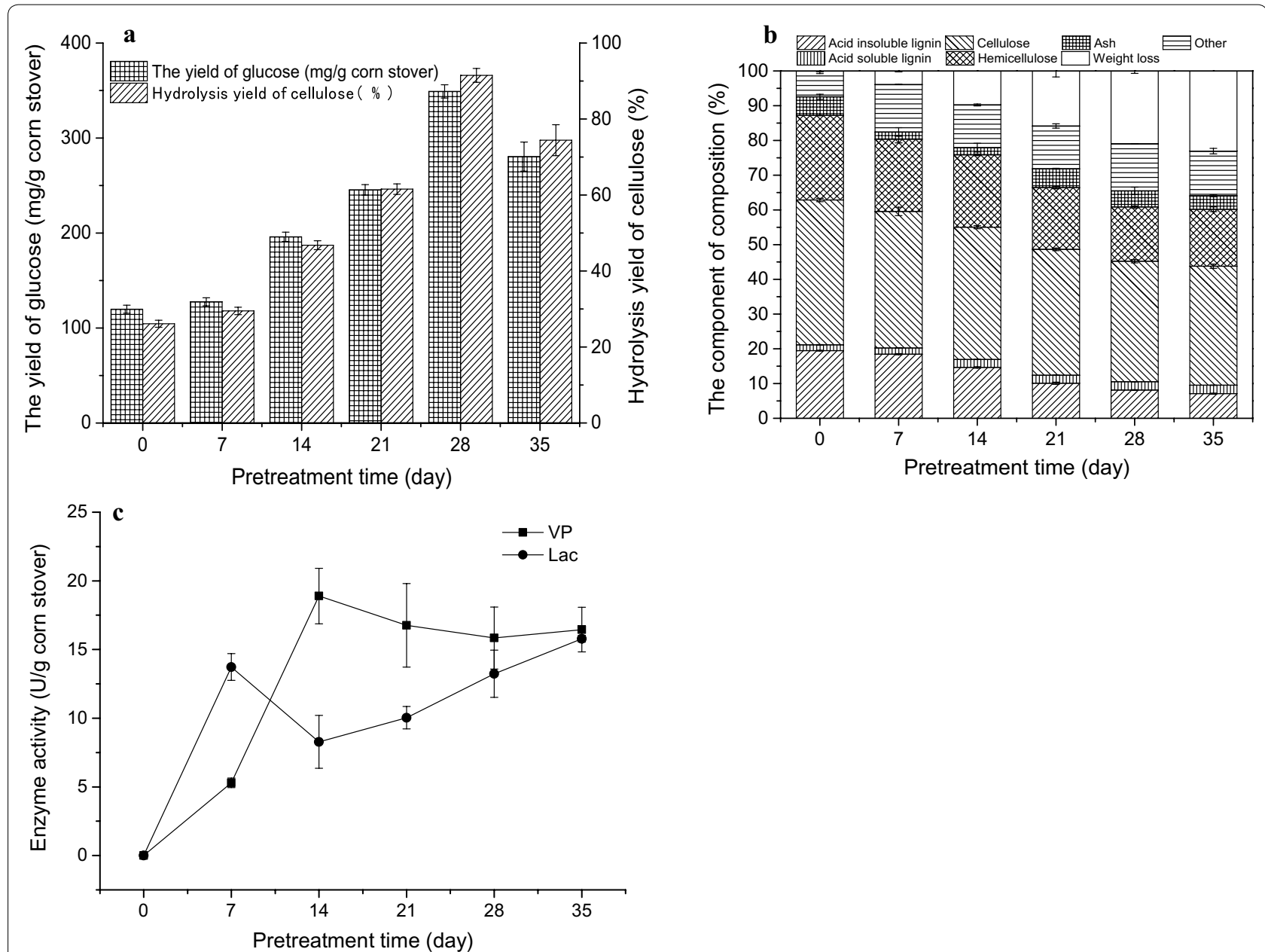

Fig. 1 a The glucose yield and hydrolysis yield of cellulose after enzymatic hydrolysis of corn stover pretreated with $P$. vitreus for different times. $\mathbf{b}$ The component analysis of corn stover after $P$. vitreus pretreatment for different times. $\mathbf{c}$ Enzyme production during $P$. vitreus pretreatment of corn stover 
does not produce inhibitors to fermentation [7]. The efficiency of pretreatment depended on fungus species due to versatile delignification strategies of white-rot fungi, and the delignification abilities of different fungi species vary greatly [31]. To date, only several fungi strains can improve the saccharification efficiency significantly as high as levels reached by thermochemical treatment $[28,29]$. Thus, development of novel and more efficient fungi strains like $P$. vitreus is necessary and meaningful.

Moreover, as shown in Fig. 1a, after increasing pretreatment time from 28 to 35 days, a decrease in hydrolysis yield is observed. This result can be explained by the fact that digestibility of cellulose is affected by both lignin removal and lignin modification [32]. Removal of lignin from lignocellulose increased substrate hydrophilicity and enlarged the volume of accessible pores. This allowed more cellulase to infiltrate into the lignocellulosic matrix to access cellulose [33, 34], thus improving saccharification of corn stover from 7 to 28 days of biological pretreatment. However, changes on the lignin surface take place during the pretreatment process that might increase the nonproductive absorption of cellulase could negatively influenced hydrolysis yields from 28 to 35 days of biological pretreatment $[35,36]$. This effect will be further studied in detail in a future work.

As shown in Fig. 1b, fungal pretreatment preserved most of the cellulose and removed 63.6 and $32.6 \%$ of the lignin and hemicellulose, respectively. A major drawback of biological pretreatment processes is the potential loss in sugar content. $P$. vitreus selectively degrade lignin and consume only little sugar while preserving most of the cellulose content. Although some sugar was consumed by $P$. vitreus, the final yield of glucose was improved compared to the untreated corn stover. In lignocellulosic biomass, cellulose and hemicellulose are densely packed by lignin layers, which protect them against enzymatic hydrolysis [37]. The improvement of glucose production might be mainly attributed to the oxidation of lignin by $P$. vitreus $[3,38]$. On one hand, fungal pretreatment can reduce saccharification recalcitrance of lignocellulosic biomass by lignin degradation [39]. On the other hand, biological pretreatment has also been shown to promote lignin modifications, such as changes in lignin hydrophobicity, which then decreased the unproductive adsorption of cellulase onto lignin [32]. In addition to the lignin degradation, there was a loss in hemicellulose content. Hemicellulose serves as a connection between lignin and cellulose fibrils and its degradation may contribute to reducing the natural recalcitrance of lignocellulosic substrates [40]. The decrease in hemicellulose content is likely a consequence of lignin degradation, which enhances the accessibility of hemicellulose for enzyme hydrolysis by xylanase [41]. Indeed, we detected xylanase activity (5 U/g corn stover) during the pretreatment with $P$. vitreus. Thus, the degradation of lignin promotes the degradation of hemicellulose, which also contributes to saccharification. The nonglucose sugar from hemicellulose might was a potential carbon and energy source for fungal growth. In general, fungal lignin oxidation plays an important role in improving saccharification yields of lignocellulosic substrates.

The ability of white-rot fungi to degrade lignin is mainly attributed to the release of a battery of ligninolytic enzymes [12, 13]. In order to analyze the high efficiency of this strain in enzymatic recalcitrance removal and degradation of lignin, we studied its extracellular ligninases (Fig. 1c). The extracellular extracts of pretreatment cultures at different periods were assayed to determine the different ligninolytic enzymes. Two main ligninolytic enzymes were detected during pretreatment of corn stover with $P$. vitreus. One was identified as Lac; the other was a special MnP, which could oxidize $\mathrm{Mn}^{2+}$ but was also able to oxidize veratryl alcohol (VA) and reactive black 5 (RB5) in the absence of $\mathrm{Mn}^{2+}$. This $\mathrm{MnP}$ was identified as a VP since it shares typical features of both $\mathrm{MnP}$ and LiP. For example, both VP and LiP oxidize VA, but only VP oxidizes $\mathrm{Mn}^{2+}$, RB5, and other dyes. To date, VPs had only been found in Pleurotus sp. [42, 43] and Bjerkandera sp. [44, 45]. This is the first report of a novel VP from white-rot fungus Physisporinus sp. As shown in Fig. 1d, VP displayed high activity from the 2nd week on and reached a maximum activity of $18.9 \mathrm{IU} / \mathrm{g}$ corn stover at 14 days of pretreatment. In contrast, Lac reached its maximum activity of $15.8 \mathrm{IU} / \mathrm{g}$ corn stover at later period, after 35 days of pretreatment. Interestingly, major lignin degradation occurred by day 21 of pretreatment (Fig. 1b), which implies that VP might play a key role in the degradation of lignin from $P$. vitreus.

\section{Py-GC-MS analysis of corn stover}

To obtain a more detailed insight into the chemical modifications of the lignin structure after fungal pretreatment, the untreated and 28-day treated corn stovers were analyzed by Py-GC/MS. Additional file 1 shows the pyrograms of the untreated and 28-day treated samples, which were dominated by peaks of phenolic compounds derived from the lignin moiety. The identities and relative abundances of the lignin-derived compounds released are listed in Table 1 . In both samples, syringyl(S-) and guaiacyl (G-)-type phenols were released, with a predominance of the latter and similar distribution patterns, together with minor amounts of $p$-hydroxyphenyl (H-)-type phenols, which is in agreement with previous reports $[46,47]$. After fungal pretreatment, the total abundance of lignin-derived compounds decreased by 
Table 1 Relative peak areas (\%) of lignin-derived compounds identified by analytical pyrolysis

\begin{tabular}{|c|c|c|c|c|}
\hline \multirow[t]{2}{*}{ Label } & \multirow[t]{2}{*}{ Compound } & \multirow[t]{2}{*}{ Origin } & \multicolumn{2}{|c|}{ Peak area (\%) } \\
\hline & & & Corn stover & Fungal-treated corn stover \\
\hline 1 & Phenol & $\mathrm{H}$ & $0.7 \pm 0.0$ & $1.1 \pm 0.2$ \\
\hline 2 & 2-Methylphenol & $\mathrm{H}$ & $0.6 \pm 0.1$ & ND \\
\hline 3 & 4-Methylphenol & $\mathrm{H}$ & $0.6 \pm 0.0$ & $0.3 \pm 0.1$ \\
\hline 4 & Guaiacol & G & $4.1 \pm 0.2$ & $2.1 \pm 0.1$ \\
\hline 5 & 2,4-Dimethylphenol & $\mathrm{H}$ & $0.1 \pm 0.0$ & ND \\
\hline 6 & 4-Ethylphenol & $\mathrm{H}$ & $0.6 \pm 0.1$ & $0.6 \pm 0.0$ \\
\hline 7 & 4-Methylguaiacol & G & $1.0 \pm 0.1$ & ND \\
\hline 8 & Benzofuran, 2,3-dihydro- & G & $3.6 \pm 0.1$ & $2.5 \pm 0.1$ \\
\hline 9 & 4-Ethylguaiacol & G & $1.6 \pm 0.1$ & ND \\
\hline 10 & 4-Methylguaiacol & G & $0.6 \pm 0.0$ & $0.4 \pm 0.0$ \\
\hline 11 & 4-Vinylguaiacol & G & $4.9 \pm 0.1$ & $1.8 \pm 0.1$ \\
\hline 12 & 4-Hydroxybenzaldehyde & $\mathrm{H}$ & $0.7 \pm 0.1$ & ND \\
\hline 13 & 4-(2-Propenyl)phenol & $\mathrm{H}$ & $0.4 \pm 0.0$ & ND \\
\hline 14 & Syringol & S & $4.4 \pm 0.1$ & $2.8 \pm 0.1$ \\
\hline 15 & 4-Hydroxy-3-methoxybenzyl alcohol & G & $0.7 \pm 0.0$ & ND \\
\hline 16 & 2-Methoxy-5-propenyl-Phenol & G & $0.2 \pm 0.0$ & $0.4 \pm 0.0$ \\
\hline 17 & Vanillin & G & $0.5 \pm 0.0$ & $0.8 \pm 0.1$ \\
\hline 18 & 4-Allylguaiacol & G & $0.4 \pm 0.0$ & $0.2 \pm 0.0$ \\
\hline 19 & 4-Hydroxy-3-methoxy-Benzoic acid & G & $1.6 \pm 0.0$ & $1.0 \pm 0.1$ \\
\hline 20 & (4-Hydroxy-3-methoxyphenyl)acetone & G & $0.3 \pm 0.0$ & $0.3 \pm 0.0$ \\
\hline 21 & 1,2,3-Trimethoxy-5-methylbenzene & $S$ & $1.8 \pm 0.1$ & ND \\
\hline 22 & Homovanillyl alcohol & G & $0.7 \pm 0.0$ & $0.2 \pm 0.0$ \\
\hline 23 & 3,5-Dimethoxyacetophenone & $S$ & $1.9 \pm 0.1$ & ND \\
\hline 24 & 4-Allylsyringol & $\mathrm{S}$ & $0.3 \pm 0.0$ & $0.1 \pm 0.0$ \\
\hline 25 & 4-Allylsyringol & $\mathrm{S}$ & $0.3 \pm 0.1$ & $0.1 \pm 0.0$ \\
\hline 26 & Syringaldehyde & $\mathrm{S}$ & $0.3 \pm 0.0$ & $0.3 \pm 0.0$ \\
\hline 27 & 4-Allylsyringol & $\mathrm{S}$ & $1.0 \pm 0.1$ & $0.2 \pm 0.1$ \\
\hline 28 & Acetosyringone & $\mathrm{S}$ & $0.6 \pm 0.0$ & $0.5 \pm 0.0$ \\
\hline 29 & 3,5-Dimethoxy-4-hydroxyphenylacetic acid & $S$ & $0.4 \pm 0.0$ & $0.4 \pm 0.0$ \\
\hline 30 & 3,5-Dimethoxy-4-hydroxycinnamaldehyde & $S$ & $0.1 \pm 0.0$ & ND \\
\hline Total peak areas of $\mathrm{H}$ & & & $3.6 \pm 0.1$ & $2.0 \pm 0.1$ \\
\hline Total peak areas of $\mathrm{G}$ & & & $20.2 \pm 1.5$ & $9.6 \pm 0.9$ \\
\hline Total peak areas of S & & & $11.0 \pm 0.3$ & $4.4 \pm 0.2$ \\
\hline
\end{tabular}

$S$ syringyl type lignin derivatives, $G$ guaiacyl type lignin derivatives, $H$ p-hydroxy phenylpropane

$54.0 \%$, which means that fungal treatment led to a considerable degradation of lignin. This is consistent with the component analysis of lignocellulosic materials after fungal pretreatment. In addition, the relative contents of most S-, G-, and H-type lignin derivatives decreased and even disappeared. For example, guaiacol (peak 4) derived from G-type lignin decreased by $49.5 \%$ and syringol (peak 14) derived from S-type lignin decreased by $31.2 \%$ after fungal treatment, while 4-methylguaiacol (peak 7), 4-ethylguaiacol (peak 9) derived from G-type lignin and 3,5-dimethoxyacetophenone (peak 23), 3,5-dimethoxy4-hydroxycinnamaldehyde (peak 30 ) derived from S-type lignin disappeared. After fungal delignification, the total peak area of $\mathrm{H}$-, G- and S-type lignin derivatives was reduced by $44.0,52.5$, and $60.1 \%$ respectively, indicating that $P$. vitreus preferentially degrades S-type units, followed by G-type units, and is least efficient at degrading $\mathrm{H}$-type units. Thus, the presence of more methoxy groups in the lignin correlated with a higher degradation rate by $P$. vitreus, which agrees with the finding of our previous study [48]. Compared with the raw sample, the treated sample contained less S-type lignin derivatives, which means that fungal delignification could have led to a substantial demethoxylation of lignin, and part of the $G$ 
and $\mathrm{H}$ units in the treated sample might be derived from the fungal demethoxylation of S units [49].

The basic analysis of lignin structure using $\mathrm{Py}-\mathrm{GC} /$ MS revealed that the selective white-rot fungus $P$. vitreus possesses strong demethoxylation properties and is a powerful tool for delignification. It may provide an efficient system for exploring new and effective delignification strategies.

\section{Purification and characterization of extracellular VP and Lac}

To verify the effect of ligninolytic enzymes in lignin depolymerization by $P$. vitreus, we purified and characterized the two ligninolytic enzymes we identified. As summarized in Additional file 2, Lac and VP produced by $P$. vitreus were successfully purified by the use of hydrophobic and ion-exchange chromatography after fractionation by ammonium sulfate precipitation. The specific activity of Lac and VP increased from 3.2 and $3.7 \mathrm{U} / \mathrm{mg}$ protein to 147.7 and $126.4 \mathrm{U} / \mathrm{mg}$ protein, respectively. The final yields of Lac and VP were 22.2 and $20.4 \%$ with a purification factor of 46.2- and 34.2-fold, respectively. After completion of the purification steps, both Lac and VP extracts showed a single band on both SDS-PAGE and native-PAGE (Additional file 3). The apparent molecular mass of Lac and VP in P. vitreus were estimated to be around 54.8 and $50.5 \mathrm{kDa}$, respectively, based on SDSPAGE. For native-PAGE, the 21-day culture crude extract only showed two bands: one was Lac and the other was VP, which was consistent with assaying the enzyme activity in the crude extract. This implied that Lac and VP were the main ligninolytic enzymes present during pretreatment of corn stover by $P$. vitreus.

The pH optima of Lac and VP were pH 3.5 and 4.5, respectively (Fig. 2a). Stability studies showed that VP was stable at a $\mathrm{pH}$ range of 3.0-7.5, and more than $50 \%$ of activity remained after $24 \mathrm{~h}$, while Lac was stable at a $\mathrm{pH}$ of $4.0-8.0$, and more than $50 \%$ of activity remained after $24 \mathrm{~h}$ (Fig. 2b). At acidic and neutral pH, VP retained much more residual activity than Lac. In addition, VP was highly stable at its optimum $\mathrm{pH}$, indicating a great potential for biotechnological applications. The optimal temperature of both Lac and VP was $60{ }^{\circ} \mathrm{C}$ (Fig. 2c), which is similar to most ligninolytic enzymes [48]. Thermal stability studies showed that Lac retained $70 \%$ of its activity after incubation at $60{ }^{\circ} \mathrm{C}$ for $1 \mathrm{~h}$ and was stable at and below $50{ }^{\circ} \mathrm{C}$ after incubation for $2 \mathrm{~h}$. VP was stable at and below $40{ }^{\circ} \mathrm{C}$, and retained $60 \%$ of its activity after incubation at $50{ }^{\circ} \mathrm{C}$ for $1 \mathrm{~h}$; however, VP activity decreased drastically at $60{ }^{\circ} \mathrm{C}$ (Fig. $2 \mathrm{~d}$ ). Thermal stability at higher temperature in enzyme's industrial application is advantageous, and surely the type of application would demand longer incubation times than $2 \mathrm{~h}$ with an in vitro enzyme preparation. Therefore, we further investigated that both Lac and VP retained more than 40 and $95 \%$ enzymatic activity at $40{ }^{\circ} \mathrm{C}$ and room temperature, respectively, after incubation for 2 days.

The kinetic parameters for oxidation of substrates including 2,2'-azino-bis (3-ethylbenzothiazoline-6-sulfonic acid) (ABTS), 2,6-dimethylphenol (2,6-DMP), guaiacol, $\mathrm{MnSO}_{4}, \mathrm{H}_{2} \mathrm{O}_{2}, \mathrm{RB} 5$, and VA, by purified VP and Lac are included in Table 2. Lac from P. vitreus oxidized the typical laccase substrates ABTS, 2,6-DMP, and guaiacol, and the highest affinity was observed in ABTS, as reported for many other fungal laccases [19]. VP showed the lowest $K_{m}$ value $(14.2 \mu \mathrm{M})$ for RB5, indicating that it had the highest affinity towards RB5. Moreover, $P$. vitreus VP showed a higher affinity towards VA $\left(K_{m}=213 \mu \mathrm{M}\right)$ than the VPs found in P. eryngii $\left(K_{m}=3000 \mu \mathrm{M}\right)$ [15] and B. adusta $\left(K_{m} 4000 \mu \mathrm{M}\right)$ [50]. A typical lignin polymer is $10-15 \%$ phenolic in composition, while the remaining $85-90 \%$ consist of nonphenolic polymer, which possesses a high redox potential [16]. RB5 and VA represent the high redox potential compounds and nonphenolic lignin model compounds. The high reactivity of VP with high oxidation-reduction potential compounds such as RB5 and VA indicates that VP has a strong ability for delignification.

The redox catalytic potentials of VP and Lac were determined by cyclic voltammetry and the $\mathrm{CV}$ data were shown in the Additional file 4. The redox potential of Lac in this study is $0.578 \mathrm{eV}$, as reported for many other fungal laccases $(0.48-0.78 \mathrm{eV})$ [15]. The redox potential of VP in this study is $1.131 \mathrm{eV}$, similar to many other reported fungal VPs $(>1.0 \mathrm{eV})$ [51]. Compared to Lac, VP is a high redox potential enzyme with oxidative activity on a wide variety of substrates, which contain low and high redox potential compounds, phenolic and nonphenolic lignin units $[23,24]$. These properties of VP make this enzyme more suitable than Lac for delignification in biorefinery processes.

\section{Oxidation of lignin model compounds by purified VP and Lac from $P$. vitreus}

Six monomeric lignin model compounds and two dimeric lignin model compounds (Fig. 3) were used to study the reactions of Lac and VP with lignin: cinnamic acid (1), 3-methoxycinnamic acid (2), 3,5-dimethoxycinnamic acid (3), p-coumaric acid (4), ferulic acid (5), sinapic acid (6), guaiacylglycerol $\beta$-guaiacyl ether (7), and dehydrodivanillic alcohol (8). These monomeric and dimeric lignin model compounds represent substructures and linkages similar to those found in native lignin, respectively.

The six monomeric lignin model compounds (Fig. 316), which represented three types of units in the lignin structure, are referred to as $\mathrm{H}, \mathrm{G}$, and S [52]. These 


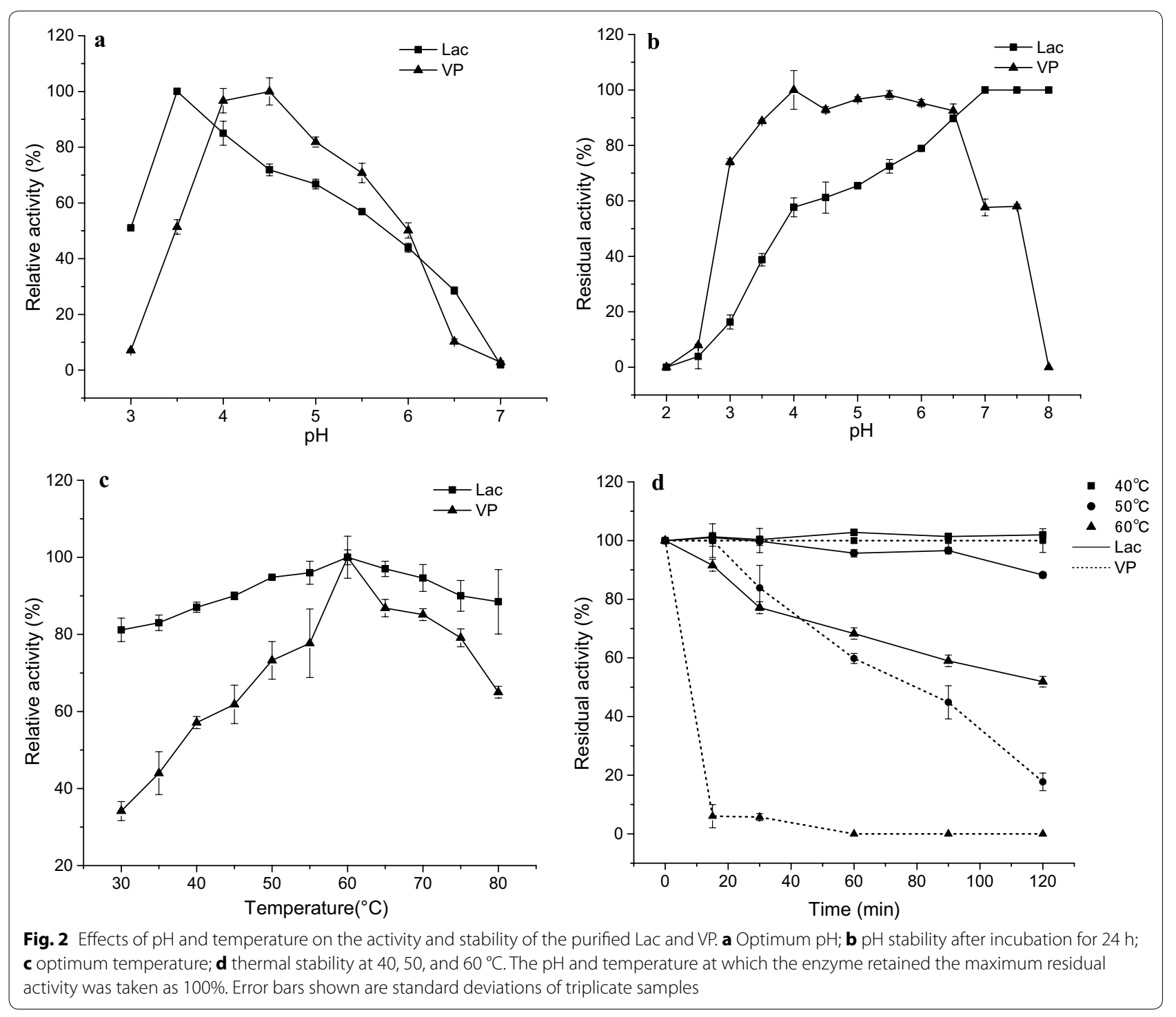

Table 2 Substrate specificities of Lac and VP purified from $P$. vitreus

\begin{tabular}{|c|c|c|c|c|c|c|c|c|c|c|}
\hline \multirow[t]{2}{*}{ Substrate } & \multirow[t]{2}{*}{ Wavelength $(\mathrm{nm})$} & \multirow[t]{2}{*}{$\begin{array}{l}\text { Molar extinction } \\
\text { coefficient } \varepsilon\left(\mathrm{L} \mathrm{mol} \mathrm{cm}^{-1}\right)\end{array}$} & \multicolumn{2}{|c|}{$K_{m}\left(\mathrm{~mol} \mathrm{~L}^{-1}\right)$} & \multicolumn{2}{|c|}{$\begin{array}{l}V_{\max } \\
\left(\mu \mathrm{mol} \mathrm{L}^{-1} \min ^{-1}\right)\end{array}$} & \multicolumn{2}{|c|}{$K_{\mathrm{cat}}\left(\mathrm{s}^{-1}\right)$} & \multicolumn{2}{|c|}{$\begin{array}{l}K_{\text {cat }} / K_{m} \\
\left(\mathrm{~s}^{-1} \mathrm{mM}^{-1}\right)\end{array}$} \\
\hline & & & Lac & VP & Lac & VP & Lac & VP & Lac & VP \\
\hline ABTS & 420 & 36,000 & $1.3 \times 10^{-5}$ & $3.5 \times 10^{-5}$ & 16.8 & 32.3 & 22.8 & 17.2 & 1791.9 & 487.5 \\
\hline 2,6-DMP & 470 & 49,600 & $2.8 \times 10^{-4}$ & $4.4 \times 10^{-5}$ & 5.2 & 66.7 & 7.1 & 35.5 & 25.1 & 804.2 \\
\hline Guaiacol & 465 & 12,100 & $9.0 \times 10^{-4}$ & $1.3 \times 10^{-4}$ & 1.7 & 85.5 & 2.2 & 45.5 & 2.5 & 347.1 \\
\hline $\mathrm{MnSO}_{4}$ & 270 & 11,590 & - & $5.4 \times 10^{-5}$ & - & 18.2 & - & 9.7 & - & 179.1 \\
\hline $\mathrm{H}_{2} \mathrm{O}_{2}$ & 270 & 11,590 & - & $4.4 \times 10^{-5}$ & - & 39.7 & - & 21.1 & - & 475.4 \\
\hline RB5 & 598 & 59,800 & - & $1.4 \times 10^{-5}$ & - & 14.5 & - & 7.7 & - & 543.2 \\
\hline VA & 310 & 4700 & - & $2.1 \times 10^{-4}$ & - & 23.1 & - & 12.3 & - & 57.7 \\
\hline
\end{tabular}




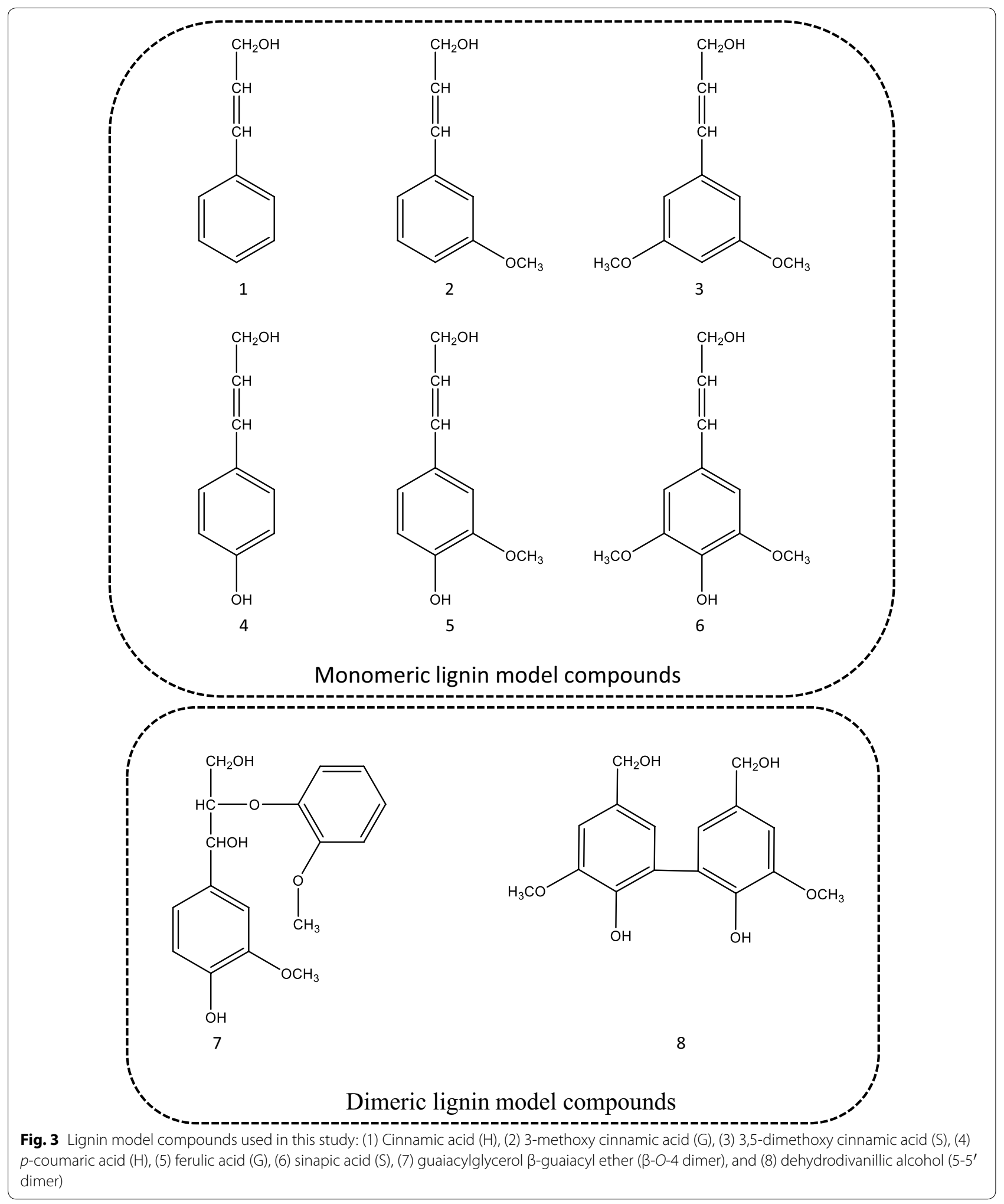


compounds were divided into phenolic and nonphenolic structures and differ in their methoxylation levels. Both Lac and VP could oxidize the three types of phenolic monomeric lignin model compounds (4-6) completely. In addition, VP was able to oxidize nonphenolic monomeric lignin model compounds partially, and was able to degrade $20.6 \pm 1.8 \%$ of the $\mathrm{H}$ - (1), $27.4 \pm 1.1 \%$ of the G- (2), and $39.3 \pm 1.2 \%$ of the S-type compound (3) after $48 \mathrm{~h}$ (Table 3). It appears that the more methoxy groups the lignin model compound contained, the higher the degradation ratio was [53]. This is consistent with the observation that analysis of lignin structure by Py-GC/MS as aforementioned, which revealed that fungal pretreatment predominantly led to the degradation of S-type lignins, followed by G- and H-type ones.Lac had no effect on nonphenolic monomeric lignin model compounds; however, VP could oxidize both phenolic and nonphenolic lignin units. Differences in substitution were expected to cause differences in the redox potentials of the lignin model compounds, which might have been reflected in the reactivity with the two different ligninolytic enzymes [53]. Laccases have a low redox potential, and it does not have sufficient energy to extract electrons from the nonphenolic aromatic substrates [54]. VP combined the catalytic properties of both LiP and MnP with high redox potential [20], which broadens the substrate specificity of VP and enabled it to attack both phenolic and nonphenolic compounds, which comprise $80-90 \%$ of the lignin [55].

To investigate the ability of VP and Lac to break linkages in lignin, two model dimers, $\beta-O-4$ (7) and $5-5^{\prime}(8)$, were used, which represent the most abundant (more than $50 \%$ of all interunit linkages) and the most resistant $(\mathrm{C}-\mathrm{C}$ linkage) interunit linkages in native lignin, respectively $[13,19]$. Additional file 5a shows the HPLC chromatograms for the reaction of $\beta-O-4$ dimer with VP; the amount of substrate decreased dramatically upon treatment with VP, and two new major peaks were observed. Analysis of these two new peaks at $4.5 \mathrm{~min}$ and $5.8 \mathrm{~min}$ by LC-ESI-MS gave $m / z$ values of $637[\mathrm{M}-\mathrm{H}]^{-}$and $183[\mathrm{M}+\mathrm{H}]^{+}$, respectively (Table 4), which indicates that the oxidization of $\beta-O-4$ dimer by VP may occur via depolymerization to a monomer and polymerization to a tetramer simultaneously. Sale and Kenneth [56] recently reported that VP could convert $\beta-O-4$ lignin dimer to monomeric products, but this reaction was competing with repolymerization. By optimizing the reaction conditions, such as VP loading, $\mathrm{H}_{2} \mathrm{O}_{2}$ concentration, and $\mathrm{pH}$, the equilibrium between depolymerization and polymerization could be controlled to a certain extent [56].

Table 3 Monomeric lignin model compounds degradation by Lac and VP of $P$. vitreus

\begin{tabular}{|c|c|c|c|c|c|c|}
\hline \multicolumn{3}{|c|}{ Phenolic lignin model compounds } & \multirow{2}{*}{$\begin{array}{l}\text { Lignin structure } \\
\text { types }\end{array}$} & \multicolumn{3}{|c|}{ Nonphenolic lignin model compounds } \\
\hline Substrate $^{a}$ & $\begin{array}{l}\text { Different enzyme } \\
\text { addition }\end{array}$ & $\begin{array}{l}\text { Degradation ratio } \\
\text { (\%) }\end{array}$ & & Substrate $^{a}$ & $\begin{array}{l}\text { Different enzyme } \\
\text { addition }\end{array}$ & $\begin{array}{l}\text { Degradation ratio } \\
\text { (\%) }\end{array}$ \\
\hline \multirow[t]{2}{*}{ p-coumaric acid (4) } & VP & $97.4 \pm 1.4$ & \multirow[t]{2}{*}{$\mathrm{H}$} & \multirow[t]{2}{*}{ Cinnamic acid (1) } & VP & $20.6 \pm 1.8$ \\
\hline & Lac & $98.7 \pm 2.1$ & & & Lac & $0.0 \pm 0.0$ \\
\hline \multirow[t]{2}{*}{ Ferulic acid (5) } & VP & $98.2 \pm 1.0$ & \multirow[t]{2}{*}{ G } & \multirow{2}{*}{$\begin{array}{l}\text { 3-Methoxy cin- } \\
\text { namic acid (2) }\end{array}$} & VP & $27.4 \pm 1.1$ \\
\hline & Lac & $98.2 \pm 0.9$ & & & Lac & $0.0 \pm 0.0$ \\
\hline \multirow[t]{2}{*}{ Sinapic acid (6) } & VP & $99.3 \pm 0.2$ & \multirow[t]{2}{*}{$\mathrm{S}$} & \multirow{2}{*}{$\begin{array}{l}\text { 3,5-Dimethoxy cin- } \\
\text { namic acid (3) }\end{array}$} & VP & $39.3 \pm 1.2$ \\
\hline & Lac & $99.2 \pm 1.97$ & & & Lac & $0.0 \pm 0.0$ \\
\hline
\end{tabular}

${ }^{a}$ Numbers corresponding to compounds in Fig. 3 are included in brackets

Table 4 Molecular ions detected by LC-ESI-MS for the main products of dimeric lignin model compounds in VP-catalyzed reactions

\begin{tabular}{|c|c|c|c|c|}
\hline Substrate & Retention time (min) & Product peak $^{a}$ & $m / z$ & Proposed products \\
\hline \multirow[t]{2}{*}{7 ( $\beta$-O-4 dimer) } & 4.5 & A & $637[\mathrm{M}-\mathrm{H}]^{-}$ & $\beta-O-4$ tetramer \\
\hline & 5.8 & B & $183[\mathrm{M}+\mathrm{H}]^{+}$ & Dihydroconiferyl alcohol \\
\hline \multirow[t]{5}{*}{8 (5-5' dimer) } & 4.5 & C & $153[\mathrm{M}-\mathrm{H}]^{-}$ & Vanillic alcohol \\
\hline & 5.2 & D & $167[\mathrm{M}-\mathrm{H}]^{-}$ & Vanillic acid \\
\hline & 5.7 & E & $303[\mathrm{M}-\mathrm{H}]^{-}$ & $\begin{array}{l}\text { 2',6-Dihydroxy-5'-(hydroxymethyl)-3',5-dimethoxy-[1,1'-biphenyl]- } \\
\text { 3-carbaldehyde }\end{array}$ \\
\hline & 6.3 & F & $151[\mathrm{M}-\mathrm{H}]^{-}$ & Vanillic aldehyde \\
\hline & 8.4 & G & $301[\mathrm{M}-\mathrm{H}]^{-}$ & Dehydrodivanillic aldehyde \\
\hline
\end{tabular}

\footnotetext{
a Product peaks marked on HPLC chromatograms in Fig. 4
} 
Additional file $5 \mathrm{~b}$ illustrates the HPLC chromatograms for the reaction progress of $5-5^{\prime}$ dimer with VP; the amount of 5-5' dimer decreased dramatically upon treatment with VP and a series of new peaks was observed. Analysis of the new major peaks at 4.5, 5.2, 5.7, 6.3, and $8.4 \mathrm{~min}$ by LC-MS gave $\mathrm{m} / \mathrm{z}$ values of $153[\mathrm{M}-\mathrm{H}]^{-}$, $167[\mathrm{M}-\mathrm{H}]^{-}, 303[\mathrm{M}-\mathrm{H}]^{-}, 151[\mathrm{M}-\mathrm{H}]^{-}$, and 301 $[\mathrm{M}+\mathrm{H}]^{+}$, respectively (Table 4 ). This indicates that the degradation of $5-5^{\prime}$ dimer by VP occurs not only via the oxidation of side chains but also via cleavage of the $5-5^{\prime}$ linkage, which generated monomeric products, such as vanillic alcohol, vanillic aldehyde, and vanillic acid. To be representative of more condensed lignin structures, many researchers have studied $5-5^{\prime}$ model compounds, which resulted in bond cleavage through oxidative side-chain reactions, but no cleavage of the actual $5-5^{\prime}$ bond $[19,57$, 58]. Lignin with relatively high numbers of $\mathrm{C}-\mathrm{C}$ linkages compared to ether linkages are often referred to as condensed lignin [59]. Condensed lignin is frequently more rigid and less prone to degradation. In this study, we first found VP could cleave the actual $5-5^{\prime}$ linkage in vitro. In contrast, treatment of both $\beta-O-4$ and $5-5^{\prime}$ dimer with Lac led to the formation of precipitates, and then the reaction of supernatants with Lac was analyzed by HPLC which did not detect any compounds. These results indicated that Lac could not depolymerize the dimer to monomers. The formation of precipitates was due to the fact that Lac leads to polymerization of $\beta-O-4$ and $5-5^{\prime}$ dimer, which were consistent with previous reports. Ramalingam [18] treated the $\beta-O-4$ dimer with two types of Lac, and both treatments led to polymerization and the formation of precipitate; Lahtinen [60] also reported that polymerization of oligomers is a well-known reaction in the Lac oxidation of $\beta-O-4$ guaiacylic lignin model compounds. Lac caused polymerization via phenoxy radical coupling $[61,62]$, and the most likely structure formed by $\mathrm{C}-\mathrm{C}$ coupling of the free phenolic coupling would be the biphenyl structure $[18,60,61]$. Phenolic $5-5^{\prime}$ dimer can also further polymerize via phenoxy radical coupling to precipitate $[57,60]$. Compared with the polymerization of $\beta-O-4$ and $5-5^{\prime}$ dimer by Lac, VP could break both $\beta-O-4$ and $5-5^{\prime}$ linkages, which are the predominant linkage type and the most difficult-to-degrade linkage type in native lignin, respectively. In summary, these remarkable ability of VP to degrade lignin might be a key factor that confers $P$. vitreus its high efficiency (hydrolysis yield of cellulose was $91.5 \%$ after $P$. vitreus pretreatment) as a pretreatment system.

\section{Enhancement of the enzymatic hydrolysis of corn stover by VP from $P$. vitreus}

We next investigated the effectiveness of VP and Lac in corn stover bioconversion by including these ligninolytic enzymes in the enzymatic hydrolysis step. As shown in Fig. 4, the hydrolysis of the lignocellulosic material using VP as a supplement to the commercial cellulase significantly improved the yield of glucose by $14.1 \%$ compared to cellulase alone $(P<0.05)$, but Lac has no effect on the hydrolysis $(P>0.05)$. This is consistent with the observation that Lac and VP have different ability in degradation of lignin model compounds investigated above. The VP used in this study could oxidize nonphenolic lignin units and break main linkages in lignin, which possibly improves the accessibility of cellulase to cellulose within the biomass [2, 3, 63]. In contrast, Lac could not oxidize nonphenolic lignin units and break main linkages in lignin, which limited delignification of Lac to reduce the enzymatic recalcitrance of biomass. Moreover, when commercial cellulase was supplemented with both Lac and VP together, the yield of glucose was similar to that with VP supplementation alone $(P>0.05)$. VP improved and Lac had no effect on the enzymatic hydrolysis of corn stover, which further indicated that VP is a key enzyme in the degradation of lignin from $P$. vitreus.

In recent years, many studies have demonstrated that white-rot fungal pretreatment can enhance the enzymatic hydrolysis of lignocellulose, which are due to versatile delignification strategies of white-rot fungi [31]. Its efficiency in these processes has been mainly attributed to the release of different ligninolytic enzymes $[12,13]$. However, it remains unclear which fungal delignification strategy based on ligninolytic enzyme plays a key role in unlocking the recalcitrant structure of lignocellulase and improves the enzymatic hydrolysis greatly. A detailed

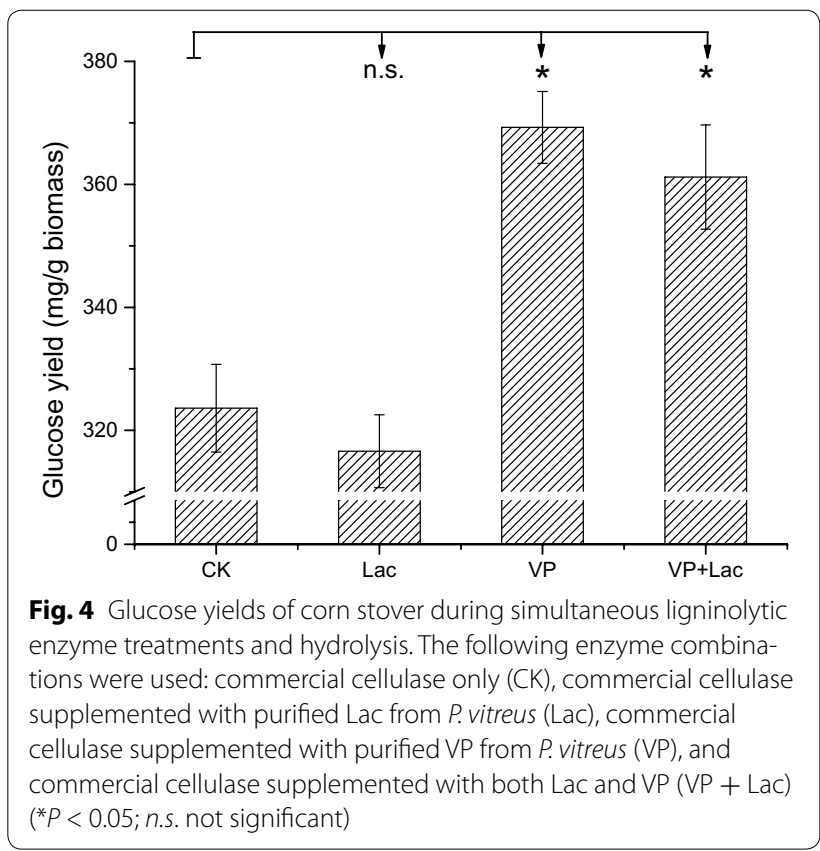


understanding of fungal delignification strategy will contribute to the development of lignocellulose biorefinery strategies based on the ligninolytic enzymes from whiterot fungi. Fungal pretreatment has some advantages, it is low-cost, environmentally friendly, and does not produce inhibitors to fermentation, while the potential loss in sugar content and long incubation times hinder its industrial applications [64, 65]. Therefore, the treatment with the effective ligninolytic enzymes from fungi in vitro was imperative. Bio-treatment with the VP in vitro enhances the glucose yield after hydrolysis similar to fungal pretreatment but without the consumption of sugar during the pretreatment process. We are the first to report that VP can improve the enzymatic hydrolysis of corn stover in vitro. This opens the way to seek more efficient VPs for the enhancement of enzymatic hydrolysis.

\section{Conclusions}

In the study, firstly, a new fungal isolate, Physisporinus vitreus was found to show a strong potential to enhance the enzymatic hydrolysis of lignocellulosic biomass. After pretreatment with $P$. vitreus, the saccharification of corn stover was significantly enhanced to $349.1 \mathrm{mg} \mathrm{g}^{-1}$ biomass (yield of glucose) and 91.5\% (hydrolysis yield of cellulose), as high as levels reached by thermochemical treatment $[28,29]$ and reaches levels similar to that of biomass pretreated using thermochemical processes $[5$, $6,30]$. Analysis of the lignin structure after pretreatment with $P$. vitreus using $\mathrm{Py}-\mathrm{GC} / \mathrm{MS}$, revealed significant demethoxylation and lignin degradation by $P$. vitreus, suggesting that $P$. vitreus is an efficient lignin-degrading fungus. Then study of extracellular ligninases from this highly efficient pretreatment system, we found a novel delignification strategy was based on VP, which could oxidize both phenolic and nonphenolic lignin units and break different linkages in lignin. Moreover, VP improved the enzymatic hydrolysis of corn stover in vitro reached to the level of biological treatment. On this basis, a new and efficient VP treatment system was established, and the role of VP in biological pretreatment also was verified. Moreover, we firstly indicated that VP can improve the enzymatic hydrolysis of corn stover in vitro.

Overall, the VP from P. vitreus in this study shows a potential use in lignin depolymerization, which makes it a really interesting enzyme for biotechnological applications, such as production of biofuel and other high valueadded bio-based materials.

\section{Methods}

\section{Fungus and inoculum preparation}

Physisporinus vitreus was isolated from stone seam at the Huazhong University of Science and Technology and identified based on its macro- and microscopic morphology. The correct identity of $P$. vitreus was further confirmed by comparing the nucleotide sequence of the internal transcribed spacer (ITS) region of the nuclear ribosomal RNA gene with that of related strains in the GenBank database [66, 67]. The GenBank Accession Number of $P$. vitreus is KU958554. P. vitreus was cultured on potato extract agar slants for 7 days at $28{ }^{\circ} \mathrm{C}$. Five disks ( $1 \mathrm{~cm}$ in diameter) of inocula were grown on potato extract broth for 5 days $\left(150 \mathrm{rpm}, 28^{\circ} \mathrm{C}\right)$. This new isolate belongs to Physisporinus sp. which has no potential hazards for plants and has been reported for engineering value-added wood products [27]. The potential hazards of this isolate for animals and the human have not been reported.

\section{Pretreatment}

Corn stover was collected from HuBei (China) and dried at $40{ }^{\circ} \mathrm{C}$ in an oven for 3 days. Raw corn stover was smashed to pass through a $0.45-\mathrm{mm}$ screen. The biological pretreatments with $P$. vitreus were carried out in 250$\mathrm{mL}$ Erlenmeyer flasks with $2 \mathrm{~g}$ ground corn stover and $5 \mathrm{~mL}$ distilled water with $0.01 \mathrm{mmol} \mathrm{L}{ }^{-1} \mathrm{MnSO}_{4}$. Flasks were sterilized in the autoclave for $40 \mathrm{~min}$ at $121{ }^{\circ} \mathrm{C}$ and aseptically inoculated with $2-\mathrm{mL}$ fungal inocula. Cultures were maintained statically at $28^{\circ} \mathrm{C}$ for $1,2,3,4$, and 5 weeks and then dried at $60^{\circ} \mathrm{C}$ for 3 days for the following saccharification and chemical component analysis.

\section{Enzymatic hydrolysis of corn stover}

Enzymatic hydrolysis of corn stover (raw and fungaltreated) were performed at $2 \%$ substrate concentration $(\mathrm{w} / \mathrm{v})$ in $50 \mathrm{mmol} \mathrm{L}^{-1}$ sodium acetate buffer (pH4.8). Cellulase (C9748, Sigma-Aldrich) was added at an enzyme loading of $30 \mathrm{FPU}$ (filter paper unit)/g dry substrate. To prevent microbial contamination, sodium azide $(0.05 \%$, $\mathrm{w} / \mathrm{v}$ ) was added to the mixture. The samples were incubated in a controlled reciprocal shaking water bath at $50{ }^{\circ} \mathrm{C}, 150 \mathrm{rpm}$ for $72 \mathrm{~h}$. The glucose concentration was measured by high-performance liquid chromatography (HPLC) system (model 1000, Shimadzu, Japan) using a column (Sugar Pak 1; Waters Ltd, Milford, US) and a refractive index (RI) detector. The mobile phase used was deionized water. The column was used at a flow rate of $0.6 \mathrm{~mL} / \mathrm{min}$ and a column temperature of $75{ }^{\circ} \mathrm{C}$. The glucose yields were calculated using the following equations:

Glucose yield $\left(\mathrm{mg} \mathrm{g}^{-1}\right)=\frac{\mathrm{mg} \text { of glucose after enzymatic hydrolysis }}{\mathrm{g} \text { of raw corn stover }}$

Hydrolysis yield of cellulose (\% )

$$
=\frac{\mathrm{g} \text { of glucose after enzymatic hydrolysis } \times 100}{\mathrm{~g} \text { of glucan in raw corn stover } \times 1.11} \text {. }
$$


Sample weight loss was taken into account for yield estimation; all results were calculated from the original biomass.

\section{Chemical component analysis of corn stover}

The contents of acid soluble lignin (ASL), acid insoluble lignin (AIL), cellulose, and hemicellulose in all samples were determined based on the "determination of structural polysaccharides and lignin in biomass (Version 2006)" from the National Renewable Energy Laboratory (NREL). Lignin content was the summation of ASL and AIL contents [68].

\section{Enzyme extraction and assay}

To obtain enzyme extracts, sodium acetate buffer solution $\left(50 \mathrm{mmol} \mathrm{L}^{-1}, \mathrm{pH} 4.8 ; 1: 50 \mathrm{w} / \mathrm{v}\right)$ was added to solid cultures of $P$. vitreus after different pretreatment periods. The flasks were then shaken at $150 \mathrm{rpm}$ for $1 \mathrm{~h}$. The contents were filtered and centrifuged at $10,000 \times g$ for $15 \mathrm{~min}$ to get a clear supernatant, which were the extracellular enzyme extracts.

Lac, LiP, and $\mathrm{MnP}$ were analyzed in the enzyme extract as previously described [48]. In addition, VP activity was assayed by monitoring the oxidation of $1 \mu \mathrm{mol}$ RB5 (Sigma-Aldrich) in $100 \mathrm{mmol} \mathrm{L}^{-1}$ sodium tartrate at pH $3\left(\varepsilon_{598}=47,600 \mathrm{~L} \mathrm{~mol}^{-1} \mathrm{~cm}^{-1}\right)$ in the presence of $0.1 \mathrm{mmol} \mathrm{L}-1 \mathrm{H}_{2} \mathrm{O}_{2}$. The total protein concentration of each sample was measured by the BCA Protein Assay Kit (Beyotime Institute of Biotechnology, China) following the manufacturer's instructions.

\section{Py-GC/MS analysis}

Analytical pyrolysis of corn stover was performed using a Pyroprobe 5200 analytical pyrolyzer (CDS Analytical Inc.) at $500{ }^{\circ} \mathrm{C}$ for one minute. The volatile pyrolysis products were analyzed using a gas chromatograph (Agilent 7890A) equipped with a mass spectrometer (5975CMSD) and HP-5MS column using the following chromatograph: $3 \mathrm{~min}$ isothermal at $40{ }^{\circ} \mathrm{C}$, followed by $5{ }^{\circ} \mathrm{C} \mathrm{min}-1$ to $150{ }^{\circ} \mathrm{C}, 10{ }^{\circ} \mathrm{C} \mathrm{min}{ }^{-1}$ to $250{ }^{\circ} \mathrm{C}$, and a final isothermal step at $250{ }^{\circ} \mathrm{C}$ for $25 \mathrm{~min}$. The MS was performed under $70 \mathrm{eV}$ EI conditions with a range from 29 to $600 \mathrm{~m} / \mathrm{z}$. The pyrolysis products were identified based on the reported literature and by comparing the mass spectra with the NIST mass spectrum library [69, 70]. Peak molar areas were calculated for the corn stoverderived products, the summed areas were normalized to 100 , and the data for three repetitive analyses were averaged and expressed as percentages.

\section{Purification and characterization of extracellular Lac and VP}

At the peak of Lac and VP activity, crude enzyme extracts were harvested as described previously. The cell-free filtrates were then subjected to ammonium sulfate fractionation. First, crude Lac and VP extracts were brought to 40 and $30 \%$ saturation, respectively, by gradual addition of ammonium sulfate. Then, the precipitated proteins were removed by centrifugation at $10,000 \times g$ for $15 \mathrm{~min}$, and more solid ammonium sulfate was added to achieve 80 and $70 \%$ saturation for crude Lac and VP extracts, respectively, followed by keeping for overnight at $4{ }^{\circ} \mathrm{C}$. On the next day, the precipitates were collected by centrifugation at $10,000 \times g$ for $15 \mathrm{~min}$ and dissolved in $20 \mathrm{mmol} \mathrm{L}^{-1}$ sodium acetate buffer ( $\left.\mathrm{pH} 4.8\right)$. After dialysis and concentration, these crude Lac and VP solutions were purified by alternate use of ion-exchange and hydrophobic chromatography equilibrated with $20 \mathrm{mmol} \mathrm{L}^{-1}$ sodium acetate buffer at $\mathrm{pH} 4.8$ [48]. The fractions with Lac and VP activity were collected, concentrated, and dialyzed by ultrafiltration. The purity of Lac and MnP was confirmed by SDS-PAGE and native-PAGE, which were performed on a $5 \%$ stacking gel and a $12 \%$ resolving gel in a mini-electrophoresis apparatus (BioRad, USA). The protein bands were visualized by staining with Coomassie Brilliant Blue R-250 in SDS-PAGE and staining with $A B T S$ and $\mathrm{H}_{2} \mathrm{O}_{2}$ in native-PAGE. The molecular weights of purified Lac and VP were estimated by SDSPAGE in comparison to prestained standard proteins $(15-170 \mathrm{kDa})$. Moreover, we conducted the following studies using these purified Lac and VP.

To study the optimum $\mathrm{pH}$, the Lac activity on ABTS, and the VP activity on $\mathrm{MnSO}_{4}$ were individually determined in the 2 malonate buffer at a pH ranging from 3.0 to 7.0 at $25^{\circ} \mathrm{C}$. The $\mathrm{pH}$ stability was investigated in potassium chloride/hydrochloric acid buffer $(\mathrm{pH}$ range from 1.0 to 2.0) and citrate-phosphate buffer ( $\mathrm{pH}$ range from 2.5 to 8.0 ) by incubating the enzymes for $24 \mathrm{~h}$ at $30{ }^{\circ} \mathrm{C}$, followed by activity measurements. The optimal temperature for Lac and VP activity was determined from 30 to $80^{\circ} \mathrm{C}$. The thermal stability was measured by incubating Lac and VP at a temperature range of $40-60{ }^{\circ} \mathrm{C}$ for $2 \mathrm{~h}$ with samples taken periodically for activity measurements. All measurements were made in triplicate.

To determine the substrate specificities of Lac and VP, the oxidation of different substrates, ABTS, DMP, guaiacol, $\mathrm{MnSO}_{4}, \mathrm{H}_{2} \mathrm{O}_{2}, \mathrm{RB} 5$, and VA was studied in $50 \mathrm{mmol} \mathrm{L}^{-1}$ malonate ( $\mathrm{pH} 4.5$ ) and $0.1 \mathrm{mmol} \mathrm{L}^{-1} \mathrm{H}_{2} \mathrm{O}_{2}$ with or without $1 \mathrm{mmol} \mathrm{L}^{-1} \mathrm{MnSO}_{4}$. The activities of Lac and VP were determined spectrometrically using the corresponding wavelengths and absorption coefficients for each substrate $[71,72]$ (Table 3).

The oxidation-reduction potentials of Lac and VP were determined by Cyclic voltammetry (CV) experiments [73]. CV experiments were performed with an electrochemical workstation (CHI600E, Shanghai Chenhua Instruments Limited, China) attached to an analytical 
three-electrode configuration. All measurements were carried out in a $25-\mathrm{mL}$ cell at room temperature. A glassy carbon electrode (GCE) with deposited enzyme film (Lac or VP) was used as a working electrode. A platinum mesh $(2 \mathrm{~cm} \times 2 \mathrm{~cm})$ was used as the counter-electrode and a saturated calomel electrode (SCE) served as a reference electrode. Before each experiment, the surface of the glassy carbon electrode was polished on a diamond-polishing pad followed by washing with distilled water. To prepare a working electrode, a $200 \mu \mathrm{L}$ of enzyme solution in acetate buffer solution $(0.1 \mathrm{mg} / \mathrm{mL})$ was dropped onto the polished surface of the GC working electrode and allowed to dry for $15 \mathrm{~min}$ at room temperature. All CVs were recorded in $0.1 \mathrm{M}$ acetate buffer solution $(\mathrm{pH}=4.8)$ at $25{ }^{\circ} \mathrm{C}$. The electrode potential was scanned from -0.9 to $0.4 \mathrm{~V}$ at scan rate of $50 \mathrm{mV} / \mathrm{s}$ for Lac and scanned from -1.5 to $0.4 \mathrm{~V}$ at scan rate of $10 \mathrm{mV} / \mathrm{s}$ for $\mathrm{VP}$ for three cycles, respectively. Glassy carbon electrode (GCE) in aqueous solutions is considered to be an inert electrode for hydronium ion reduction.

\section{Oxidation of lignin model compounds by purified Lac and VP from $P$. vitreus}

The substrates used are summarized in Fig. 3 and included six monomeric (purchased from Sigma-Aldrich) and two dimeric lignin model compounds (synthesis according to Additional files 6, 7). Each lignin model compound was added at a final concentration of $1 \mathrm{mmol} \mathrm{L}^{-1}$ to the reaction mixtures. For VP, the reaction mixtures consisted of VP $\left(1 \mathrm{U} \mathrm{mL}^{-1}\right), \mathrm{H}_{2} \mathrm{O}_{2}\left(0.1 \mathrm{mmol} \mathrm{L} \mathrm{L}^{-1}\right)$, and $\mathrm{MnSO}_{4}$ $\left(1 \mathrm{mmol} \mathrm{L}^{-1}\right)$ in $50 \mathrm{mmol} \mathrm{L}^{-1}$ malonate buffer at $\mathrm{pH} 4.5$, and additional $\mathrm{H}_{2} \mathrm{O}_{2}$ was supplemented every $8 \mathrm{~h}$. The Lac reaction mixtures consisted of $\mathrm{Lac}\left(1 \mathrm{U} \mathrm{mL}^{-1}\right)$ in $50 \mathrm{mmol} \mathrm{L}^{-1}$ sodium acetate buffer at $\mathrm{pH} 4.8$. The reaction mixtures were incubated with the different lignin substrates at $30{ }^{\circ} \mathrm{C}$ for $48 \mathrm{~h}$, and the residual concentrations of the lignin model compounds were analyzed by HPLC using a reversed phase $\mathrm{C}_{18}$-column (WondaSil- $\mathrm{C}_{18}, 4.6 \mathrm{~mm} \times 250 \mathrm{~mm}, 5 \mu \mathrm{m}$ ). Methanol-water $(65: 35, \mathrm{v} / \mathrm{v})$ containing $0.1 \%$ formic acid was used as an eluate, and compounds were detected by UV at $270 \mathrm{~nm}$. For each test, $10 \mu \mathrm{L}$ of sample was injected and

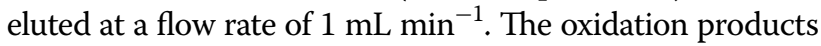
of lignin dimers treated with VP were further analyzed via LC-ESI-MS. Chromatographic separation was performed using the same column as above at $40{ }^{\circ} \mathrm{C}$ with a flow rate of $0.8 \mathrm{~mL} \mathrm{~min}^{-1}$ and an injection volume of $30 \mu \mathrm{L}$. The eluate was methanol-water $(55: 45, \mathrm{v} / \mathrm{v})$ containing $0.1 \%$ formic acid, and reaction products were detected by a UV detector at $270 \mathrm{~nm}$. LC-ESI-MS analyses were conducted in positive and negative ionization modes simultaneously. The drying gas was operated at a flow rate of $10 \mathrm{~mL} \mathrm{~min}{ }^{-1}$ at $280{ }^{\circ} \mathrm{C}$. The nebulizer pressure and the capillary voltage were 40 psig and $3500 \mathrm{~V}$, respectively.

\section{Enzymatic hydrolysis of corn stover supplementation with Lac and VP from $P$. vitreus}

In order to make the enzyme and raw materials in full contact and maximize the effect, the unpretreated corn stover used here was further ground, which may lead to higher glucose yield of control. The previous raw corn stover was ground in a $500-\mathrm{mL}$ ceramic jar with $10 \times 10-\mathrm{mm}$ ceramic ball bearings using a planetary ball mill. The total ball-milling time was $2 \mathrm{~h}$ at $400 \mathrm{rpm}$ with 5 -min breaks after every $10 \mathrm{~min}$ of milling. To test the effectiveness of different enzyme mixtures in corn stover hydrolysis, $5 \%(\mathrm{w} / \mathrm{v})$ corn stover was added to $50 \mathrm{mmol} \mathrm{L}^{-1}$ sodium citrate buffer ( $\mathrm{pH} 4.8$ ) and incubated at $30{ }^{\circ} \mathrm{C}$ at $180 \mathrm{rpm}$ for $48 \mathrm{~h}$ with the following enzyme mixtures: (i) commercial cellulase (30 FPU/g substrate) (Sigma-Aldrich); (ii) commercial cellulase plus purified Lac (100 U/g substrate); (iii) commercial cellulase plus purified VP (100 U/g substrate); and (iv) commercial cellulase plus purified Lac and VP $(100 \mathrm{U} / \mathrm{g}$ substrate each); glucose oxidase $(0.1 \mathrm{U} / \mathrm{mL})$ was added to all samples to supply $\mathrm{H}_{2} \mathrm{O}_{2}$. The release of fermentable sugar was quantified as described previously [28].

\section{Statistical analysis}

All samples were tested in triplicate. Mean values are presented with their standard errors. Multiple comparison tests were performed with ANOVA $(* P<0.05$; n.s., not significant). The experimental results were validated by statistical analysis using Origin 8.0 software.

\section{Additional files}

Additional file 1. Py-GC/MS chromatograms of (a) untreated corn stover and (b) corn stover pretreated with P. vitreus for 28 day.

Additional file 2. Summary of the purification of Lac and VP from $P$. vitreus.

Additional file 3. SDS-PAGE (a) and Native-PAGE (b) of purified VP and Lac from $P$. vitreus.

Additional file 4. Cyclic voltammograms of Lac and VP.

Additional file 5. HPLC chromatograms of products of dimeric lignin model compounds 7 (a) and 8 (b) in VP-catalyzed reactions.

Additional file 6. Synthesis scheme of guaiacylglycerol $\beta$-guaiacyl ether. Additional file 7. Synthesis scheme of dehydrodivanillyl alcohol.

\begin{abstract}
Abbreviations
P. vitreus: Physisporinus vitreus; VP: versatile peroxidase; Lac: laccase; LiP: lignin peroxidase; MnP: manganese peroxidase; ABTS: 2,2'-azino-bis (3-ethylbenzothiazoline-6-sulfonic acid); DMP: 2,6-dimethylphenol; VA: veratryl alcohol; RB5: reactive black 5; H: p-hydroxyphenyl; G: guaiacyl; S: syringyl; Py-GC/MS: Pyrolysis-gas chromatography/mass spectrometry; HPLC: high-performance liquid chromatography; LC-ESI-MS: high-performance liquid chromatography-electrospray ionization-mass spectrometry.
\end{abstract}

\section{Authors' contributions}

WK, XZ, and HY conceived and designed the experiments. XF carried out the pretreatment experiments. AA purified Lac from P. vitreus. KW carried out the 
rest of the experiments. LW synthesized the two lignin dimers. FM and JZ provided HPLC analysis. WK and HY analyzed the results and wrote the manuscript. All authors read and approved the final manuscript.

\section{Author details}

${ }^{1}$ College of Life Science and Technology, Huazhong University of Science and Technology, Wuhan 430074, People's Republic of China. ${ }^{2}$ College of Life Science and Technology, WuHan University of Technology, Wuhan 430070, People's Republic of China.

\section{Acknowledgements}

The authors thank the Centre of Analysis and Test of Huazhong University of Science and Technology for LC-ESI-MS analysis. We would like to thank Editage (https://www.editage.cn) for English language editing.

\section{Competing interests}

The authors declare that they have no competing interests.

\section{Availability of data and materials}

All data supporting the conclusions of this article are included within the manuscript and additional files.

\section{Consent for publication}

All authors consent for publication.

\section{Ethical approval and consent to participate} Not applicable.

\section{Funding}

This work was supported by the National Natural Science Foundation of China $(31570577,21404083)$ and China Postdoctoral Science Foundation (2016M602278)

\section{Publisher's Note}

Springer Nature remains neutral with regard to jurisdictional claims in published maps and institutional affiliations.

Received: 13 April 2017 Accepted: 7 September 2017

Published online: 13 September 2017

\section{References}

1. Xie S, Syrenne R, Sun S, Yuan JS. Exploration of natural biomass utilization systems (NBUS) for advanced biofuel_from systems biology to synthetic design. Curr Opin Biotechnol. 2014;27:195-203.

2. Agbor VB, Cicek N, Sparling R, Berlin A, Levin DB. Biomass pretreatment: fundamentals toward application. Biotechnol Adv. 2011;29:675-85.

3. Ding S-Y, Liu Y-S, Zeng Y, Himmel ME, Baker JO, Bayer EA. How does plant cell wall nanoscale architecture correlate with enzymatic digestibility? Science. 2012;338:1055-60.

4. Yan K, Liu F, Chen Q, Ke M, Huang X, Hu W, Zhou B, Zhang X, Yu H. Pyrolysis characteristics and kinetics of lignin derived from enzymatic hydrolysis residue of bamboo pretreated with white-rot fungus. Biotechnol Biofuels. 2016;9:1.

5. Kumar P, Barrett DM, Delwiche MJ, Stroeve P. Methods for pretreatment of lignocellulosic biomass for efficient hydrolysis and biofuel production. Ind Eng Chem Res. 2009;48:3713-29.

6. Masran R, Zanirun Z, Bahrin EK, Ibrahim MF, Lai YP, Abd-Aziz S. Harnessing the potential of ligninolytic enzymes for lignocellulosic biomass pretreatment. Appl Microbiol Biotechnol. 2016;100:1-16.

7. Alvira P, Tomás-Pejó E, Ballesteros M, Negro M. Pretreatment technologies for an efficient bioethanol production process based on enzymatic hydrolysis: a review. Bioresour Technol. 2010;101:4851-61.

8. Zhang $X Y$, Yu HB, Huang HY, Liu YX. Evaluation of biological pretreatment with white rot fungi for the enzymatic hydrolysis of bamboo culms. Int Biodeterior Biodegrad. 2007;60:159-64.
9. Machado A, Ferraz A. Biological pretreatment of sugarcane bagasse with basidiomycetes producing varied patterns of biodegradation. Bioresour Technol. 2017;225:17-22.

10. Shi J, Chinn MS, Sharma-Shivappa RR. Microbial pretreatment of cotton stalks by solid state cultivation of Phanerochaete chrysosporium. Bioresour Technol. 2008;99:6556-64.

11. Ye S, Cheng J. Hydrolysis of lignocellulosic materials for ethanol production: a review. Bioresour Technol. 2002;83:1-11.

12. Manavalan T, Manavalan A, Heese K. Characterization of lignocellulolytic enzymes from white-rot fungi. Curr Microbiol. 2015;70:485-98.

13. Hammel KE, Cullen D. Role of fungal peroxidases in biological ligninolysis. Curr Opin Plant Biol. 2008;11:349-55.

14. Knežević A, Stajić $M$, Jovanović $\vee M$, Kovačević $V$, Ćilerdžić J, Milovanović I, Vukojević J. Induction of wheat straw delignification by Trametes species. Sci Rep. 2016;6:26529.

15. Pollegioni L, Tonin F, Rosini E. Lignin-degrading enzymes. FEBS J. 2015;282:1190-213.

16. Heap L, Green A, Brown D, Dongen BV, Turner N. Role of laccase as an enzymatic pretreatment method to improve lignocellulosic saccharification. Catal Sci Technol. 2014:4:2251-9.

17. Crestini $C$, Jurasek L, Argyropoulos DS. On the mechanism of the laccase-mediator system in the oxidation of lignin. Chemistry. 2003:9:5371-8.

18. Ramalingam B, Sana B, Seayad J, Ghadessy FJ, Sullivan MB. Towards understanding of laccase-catalysed oxidative oligomerisation of dimeric lignin model compounds. RSC Adv. 2017;7:11951-8.

19. Munk L, Sitarz AK, Kalyani DC, Mikkelsen JD, Meyer AS. Can laccases catalyze bond cleavage in lignin? Biotechnol Adv. 2015;33:13-24.

20. Tsukihara T, Honda Y, Sakai R, Watanabe T, Watanabe T. Mechanism for oxidation of high-molecular-weight substrates by a fungal versatile peroxidase, MnP2. Appl Environ Microbiol. 2008;74:2873-81.

21. Morales M, Mate MJ, Romero A, Jesus Martinez M, Martinez AT, RuizDuenas FJ. Two oxidation sites for low redox potential substrates. A directed mutagenesis, kinetic, and crystallographic study on Pleurotus eryngii versatile peroxidase. J Biol Chem. 2012;287:41053-67.

22. Ruiz-Dueñas FJ, Morales M, García E, Miki Y, Martínez MJ, Martínez AT. Substrate oxidation sites in versatile peroxidase and other basidiomycete peroxidases. J Exp Bot. 2009;60:441-52.

23. Rodriguez E, Nuero O, Guillen F, Martinez AT, Martinez MJ. Degradation of phenolic and non-phenolic aromatic pollutants by four Pleurotus species: the role of laccase and versatile peroxidase. Soil Biol Biochem. 2004;36:909-16.

24. Knop D, Yarden O, Hadar Y. The ligninolytic peroxidases in the genus Pleurotus: divergence in activities, expression, and potential applications. Appl Microbiol Biotechnol. 2015;99:1025-38.

25. Hakala TK, Lundell T, Galkin S, Maijala P, Kalkkinen N, Hatakka A. Manganese peroxidases, laccases and oxalic acid from the selective white-rot fungus Physisporinus rivulosus grown on spruce wood chips. Enzyme Microbiol Technol. 2005:36:461-8.

26. Schubert M, Dengler V, Mourad S, Schwarze FWMR. Determination of optimal growth parameters for the bioincising fungus Physisporinus vitreus by means of response surface methodology. J Appl Microbiol. 2009:106:1734-42.

27. Schwarze FWMR, Schubert M. Physisporinus vitreus: a versatile white rot fungus for engineering value-added wood products. Appl Microbiol Biotechnol. 2011;92:431-40.

28. Song $L, M a F$, Zeng $Y$, Zhang $X, Y u H$. The promoting effects of manganese on biological pretreatment with Irpex lacteus and enzymatic hydrolysis of corn stover. Bioresour Technol. 2013;135:89-92.

29. Chen SL, Zhang XY, Singh D, Yu HB, Yang XW. Biological pretreatment of lignocellulosics: potential, progress and challenges. Biofuels. 2010;1:177-99.

30. Pandiyan K, Tiwari R, Rana S, Arora A, Singh S, Saxena AK, Nain L. Comparative efficiency of different pretreatment methods on enzymatic digestibility of Parthenium sp. World J Microbiol Biotechnol. 2014;30:55-64.

31. Singh R, Hu J, Regner MR, Round JW, Ralph J, Saddler JN, Eltis LD. Enhanced delignification of steam-pretreated poplar by a bacterial laccase. Sci Rep. 2017;7:42121. 
32. Moilanen U, Kellock M, Galkin S, Viikari L. The laccase-catalyzed modification of lignin for enzymatic hydrolysis. Enzyme Microbial Technol. 2011:49:492-8.

33. Xu CY, Ma FY, Zhang XY, Chen SL. Biological pretreatment of corn stover by Irpex lacteus for enzymatic hydrolysis. J Agric Food Chem. 2010;58:10893-8.

34. Kristensen JB, Thygesen LG, Claus F, Henning J, Thomas E. Cell-wall structural changes in wheat straw pretreated for bioethanol production. Biotechnol Biofuels. 2008;1:5-5.

35. Yu Z, Gwak KS, Treasure T, Jameel H, Chang HM, Park S. Effect of lignin chemistry on the enzymatic hydrolysis of woody biomass. Chemsuschem. 2014;7:1942-50.

36. Lu X, Zheng X, Li X, Zhao J. Adsorption and mechanism of cellulase enzymes onto lignin isolated from corn stover pretreated with liquid hot water. Biotechnol Biofuels. 2016;9:118.

37. Qin C, Clarke K, Li K. Interactive forces between lignin and cellulase as determined by atomic force microscopy. Biotechnol Biofuels. 2014;7:65.

38. Yu H, Liu F, Ke M, Zhang X. Thermogravimetric analysis and kinetic study of bamboo waste treated by Echinodontium taxodii using a modified three-parallel-reactions model. Bioresour Technol. 2015;185:324-30.

39. Taniguchi M, Suzuki H, Watanabe D, Sakai K, Hoshino K, Tanaka T. Evaluation of pretreatment with Pleurotus ostreatus for enzymatic hydrolysis of rice straw. J Biosci Bioeng. 2005;100:637-43.

40. Gao Z, Mori T, Kondo R. The pretreatment of corn stover with Gloeophyllum trabeum KU-41 for enzymatic hydrolysis. Biotechnol Biofuels. 2012;5:28.

41. Novy V, Krahulec S, Wegleiter M, Müller G, Longus K, Klimacek M, Nidetzky B. Process intensification through microbial strain evolution: mixed glucose-xylose fermentation in wheat straw hydrolyzates by three generations of recombinant Saccharomyces cerevisiae. Biotechnol Biofuels. 2014;7:49.

42. Martinez MJ, Ruiz-Dueñas FJ, Guillén F, Martinez AT. Purification and catalytic properties of two manganese peroxidase isoenzymes from Pleurotus eryngii. Eur J Biochem. 1996;237:424-32.

43. Min C, Shanjing Y, Zhang H, Liang X. Purification and characterization of a versatile peroxidase from edible mushroom Pleurotus eryngii. Chin J Chem Eng. 2010;18:824-9.

44. Mester T, Field JA. Characterization of a novel manganese peroxidaselignin peroxidase hybrid isozyme produced by Bjerkandera species strain BOS55 in the absence of manganese. J Biol Chem. 1998;273:15412-7.

45. Taboada-Puig R, Lú-Chau T, Moreira MT, Feijoo G, Martínez MJ, Lema JM. A new strain of Bjerkandera sp. production, purification and characterization of versatile peroxidase. World J Microbiol Biotechnol. 2011;27:115-22.

46. del Río JC, Rencoret J, Prinsen P, Martínez ÁT, Ralph J, Gutiérrez A. Structural characterization of wheat straw lignin as revealed by analytical pyrolysis, 2D-NMR, and reductive cleavage methods. J Agric Food Chem. 2012;60:5922

47. Ralph J, Lu F. The DFRC method for lignin analysis. 6. A simple modification for identifying natural acetates on lignins. J Agric Food Chem. 1998:46:4616-9.

48. Kong W, Chen H, Lyu S, Ma F, Yu H, Zhang X. Characterization of a novel manganese peroxidase from white-rot fungus Echinodontium taxodii 2538, and its use for the degradation of lignin-related compounds. Process Biochem. 2016;51:1776-83.

49. Choi J-W, Choi D-H, Ahn S-H, Lee S-S, Kim M-K, Meier D, Faix O, Scott GM. Characterization of trembling aspen wood (Populus tremuloides L.) degraded with the white rot fungus Ceriporiopsis subvermispora and MWLs isolated thereof. Holz als Roh- und Werkstoff. 2006;64:415-22.

50. Heinfling A, Ruiz-Dueñas FJ, MartíNez MAJ, Bergbauer M, Szewzyk U, MartíNez AT. A study on reducing substrates of manganese-oxidizing peroxidases from Pleurotus eryngii and Bjerkandera adusta. FEBS Lett. 1998:428:141-6

51. Hofrichter M, Ullrich R, Pecyna MJ, Liers C, Lundell T. New and classic families of secreted fungal heme peroxidases. Appl Microbiol Biotechnol. 2010;87:871-97.

52. Vanholme R, Demedts B, Morreel K, Ralph J, Boerjan W. Lignin biosynthesis and structure. Plant Physiol. 2010;153:895-905.

53. Lahtinen M, Kruus K, Boer H, Kemell M, Andberg M, Viikari L, Sipilä J. The effect of lignin model compound structure on the rate of oxidation catalyzed by two different fungal laccases. J Mol Catal B Enzym. 2009;57:204-10.
54. Sanchez C. Lignocellulosic residues: biodegradation and bioconversion by fungi. Biotechnol Adv. 2008;27:185-94.

55. Abdelaziz OY, Brink DP, Prothmann J, Ravi K, Sun M, García-Hidalgo J, Sandahl M, Hulteberg CP, Turner C, Lidén G. Biological valorization of low molecular weight lignin. Biotechnol Adv. 2016;34:1318-46.

56. Zeng J, Mills MJL, Simmons BA, Kent MS, Sale KL. Understanding factors controlling depolymerization and polymerization in catalytic degradation of [small beta]-ether linked model lignin compounds by versatile peroxidase. Green Chem. 2017;19:2145-54.

57. Crestini C, Argyropoulos DS. The early oxidative biodegradation steps of residual kraft lignin models with laccase. Bioorg Med Chem. 1998;6:2161-9.

58. Elegir G, Daina S, Zoia L, Bestetti G, Orlandi M. Laccase mediator system: oxidation of recalcitrant lignin model structures present in residual kraft lignin. Enzyme Microbial Technol. 2005;37:340-6.

59. Li Q, Xie S, Serem WK, Naik MT, Liu L, Yuan JS. Quality carbon fibers from fractionated lignin. Green Chem. 2017;19:1628-34

60. Lahtinen M, Kruus K, Heinonen P, Sipilä J. On the reactions of two fungal laccases differing in their redox potential with lignin model compounds: products and their rate of formation. J Agric Food Chem. 2009;57:8357-65

61. Rahmanpour R, Rea D, Jamshidi S, Fülöp V, Bugg TDH. Structure of Thermobifida fusca DyP-type peroxidase and activity towards Kraft lignin and lignin model compounds. Arch Biochem Biophys. 2016;594:54-60.

62. Majumdar S, Lukk T, Solbiati JO, Bauer S, Nair SK, Cronan JE, Gerlt JA. Roles of Small Laccases from streptomyces in lignin degradation. Biochemistry. 2014:53:4047-58.

63. Salvachúa D, Prieto A, Martínez ÁT. Characterization of a novel dyedecolorizing peroxidase (DyP)-type enzyme from Irpex lacteus and its application in enzymatic hydrolysis of wheat straw. Appl Environ Microbiol. 2013;79:4316-24.

64. Shrestha P, Rasmussen M, Khanal SK, van Leeuwen JH. Solid-substrate fermentation of corn fiber by Phanerochaete chrysosporium and subsequent fermentation of hydrolysate into ethanol. J Agric Food Chem. 2008;56:3918-24.

65. Shi J, Sharmashivappa RR, Chinn MS. Microbial pretreatment of cotton stalks by submerged cultivation of Phanerochaete chrysosporium. Bioresour Technol. 2009;100:4388-95.

66. Gardes M, Bruns TD. ITS primers with enhanced specificity for basidiomycetes-application to the identification of mycorrhizae and rusts. Mol Ecol. 1993;2:113-8.

67. Szentiványi O, Kiss L, Russell JC, Kovács GM, Varga K, Jankovics T, Lesemann S, Xu X-M, Jeffries P. Ampelomyces mycoparasites from apple powdery mildew identified as a distinct group based on single-stranded conformation polymorphism analysis of the rDNA ITS region. Mycol Res. 2005;109:429-38

68. Du W, Yu H, Song L, Zhang J, Weng C, Ma F, Zhang X. The promoting effect of by-products from Irpex lacteus on subsequent enzymatic hydrolysis of bio-pretreated cornstalks. Biotechnol Biofuels. 2011;4:37.

69. Ke J, Laskar DD, Chen S. Biodegradation of hardwood lignocellulosics by the western poplar clearwing borer, Paranthrene robiniae (Hy. Edwards). Biomacromol. 2011:12:1610-20.

70. Martínez AT, Rencoret J, Nieto L, Jiménez-Barbero J, Gutiérrez A, del Río JC. Selective lignin and polysaccharide removal in natural fungal decay of wood as evidenced by in situ structural analyses. Environ Microbiol. 2011:13:96-107.

71. Camarero S, Sarkar S, Ruiz-Duenas FJ, Martinez MJ, Martinez AT. Description of a versatile peroxidase involved in the natural degradation of lignin that has both manganese peroxidase and lignin peroxidase substrate interaction sites. J Biol Chem. 1999;274:10324-30.

72. Jarosz-Wilkolazka A, Luterek J, Olszewska A. Catalytic activity of versatile peroxidase from Bjerkandera fumosa at different $\mathrm{pH}$. Biocatal Biotransform. 2008;26:280-7.

73. Lai CY, Wu CH, Meng CT, Lin CW. Decolorization of azo dye and generation of electricity by microbial fuel cell with laccase-producing white-rot fungus on cathode. Appl Energy. 2017;188:392-8. 